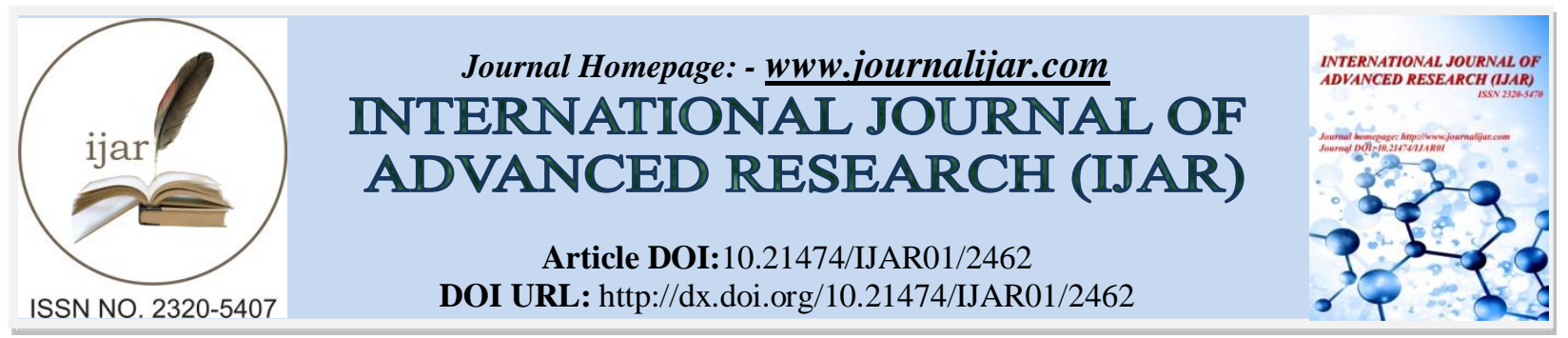

\title{
RESEARCHARTICLE
}

\section{INFLUENCE OF THREE PELLETS BASED GREEN FODDERS, PRODUCTS AND BY-PRODUCTS MAIZE ON THE GROWTH OF BRED GRASSCUTTER (THRYONOMYS SWINDERIANUS) IN BENIN.}

\section{F. F. Aizoun ${ }^{1,2}$, S. C. B. Pomalegni ${ }^{1}$, C. D. S. J. Gbemavo ${ }^{3}$, S. Farougou ${ }^{2}$, A. K .I. Youssao ${ }^{4}$ and G.A. Mensah".}

1. Laboratory of Zootechnical, Veterinary and Halieutic Research (LRZV), Centre of Agricultural Research/Agonkanmey (CRA) of the National Institute of Agricultural Research of Benin (INRAB), 01 BP 884 Master recipe, Cotonou, 01 Republic of Benin.

2. Department of Animal Production and health, Biotechnology Research Unit of Production and Animal Health, Polytechnic School of Abomey-Calavi, University of Abomey-Calavi (UAC), 01 BP 2009 Cotonou, Benin.

3. Laboratory of Biomathematics and Forest Estimates (LABEF), Faculty of Agricultural Sciences, University of Abomey-Calavi (UAC), 04 BP 1525, Cotonou, Benin.

4. University of Abomey-Calavi (UAC),Polytechnic School of Abomey-Calavi (EPAC), 2Department of Animal Production and health, Laboratory of Research in Applied Biology, 01 BP 2009 Cotonou, Benin.

\section{ManuscriptInfo}

\section{Manuscript History}

Received: 23 October 2016

Final Accepted: 21 November 2016

Published: December 2016

Key words:-

Grasscutter breeding;feed pellets; byproducts of maize;growth; Benin.

\section{Abstract}

The study aims to assess on bred grasscutter (Thryonomys swinderianus) fed with three type of pellets, the growth performances for 12 weeks. The pellets were based green fodders, products and byproducts of maize, medicinal plants and other food ingredients. A total of 27 bred grasscutters aged 7 months were used and divided into three groups of 9 grasscutters with average live weight of $1928.4 \pm$ $51.99 \mathrm{~g} ; 2286 \pm 59.52 \mathrm{~g}$ and $2077.6 \pm 46.05$ grespectively. The experimental design was a randomized complete block with three treatments (pellets) repeated three times.Each experimental unit consists of three individualgrasscutter.The results showed that the average final weight was2865,6 $\pm 63,96 \mathrm{~g}, 2818,8 \pm 134.2 \mathrm{~g}$ and $2832.6 \pm 93.73$ grespectively for pellets 1 , pellets 2 and pellets 3 . Corresponding average weight gains were $937.2 \pm 21.58 \mathrm{~g}, 532.80 \pm$ $95.41 \mathrm{~g}$ and $755 \pm 66.06$ grespectivelyfor pellets 1,2 and 3 with a significant difference $(\mathrm{p}<0.05)$. The highest average daily feed consumption $(62.29 \pm 1.80 \mathrm{~g})$ was recorded in animals fed with the pellets 1 with the best average daily gain $(10.41 \pm 0.24 \mathrm{~g} /$ day $)$ followed by those fed with the pellets $3(8.39 \pm 0.73 \mathrm{~g} / \mathrm{day})$. A significant difference was obtained between theaverage daily gains of three groups of grasscutter $(\mathrm{p}<0.05)$. The pellets 1 could be used as a complete food for the sustainable production of grasscutters.

Copy Right, IJAR, 2016,. All rights reserved.

\section{Introduction:-}

Started in 1983 with a methodological approach of development research in Benin, grasscutter breeding constitute an effective means of reconciling nature conservation objectives and meeting the food needs of populations (Mensahet al. 2001). Since its start, grasscutter breeding is booming in Benin with more than 70000 grasscutter in 
captivity for more 3000heads breeders (Mensah et al., 2013).Faced with this changing herd of cane rat through the efforts over the years, some constraints remain to be overcome in many areas especially in food. Indeed food, an important position in animal production, is a serious constraint and a major concern for all farmers in general and aulacodiculteurs installed in urban and péri-urban areas of Benin in particular(Mensah, 2000). Grasscutter is fed with a variety of fodder which is the basis of their food and a food supplement of energetic matter, nitrogen, vitamins and minerals (Tolebaet al., 2007; Tolebaet al., 2009).The nutritional value of these forages are low, breeders have always resort to dietary supplement. Thus the low nutritional value of fodder and difficulties proper rationing generate growth retardation, from where obtaining low weight militating in disfavor of the selection of reproductives and animals held for sale (Soroet al., 2014).

In Benin, the green fodders are very abundant in the rainy season and very rare in the dry season. Furthermore, agricultural products and agro-industrial and especially the products and by-products of maize available for use during the lean period is not sufficiently valued. The composition of suitable fodder or with conventional fodder or food ingredients that will enhance the optimum performance of the grasscutter is yet to be established (Okeke and Mogbo, 2013). The grasscutters of breeding by eating behavior which is to sort between the particles of the food makes this animal a wasteful 70\% of fodders which are served him (Mensahet al., 1996; Mensah, 1997; Traoré, 2010). So several authors have undertaken studies on the possibility to feed the grasscutter with pellets (Aïzounet al., 2015;Pomalegniet al., 2015). The Granulation of rations allows the sort of food particles by animals and control the proportions of different food components ingested by the animal. Which allows of determines the digestibility of each food component with more accurately than when food is distributed in the state (Traoreet al., 2009; Yapi, 2013).Being given a large margin of progress of parameters zootechnical in breed grasscutters is denoted through the diversity of the results recorded in several experiments (Joriet al., 2001), and that the products and by-products of maize are available to be valorize ; it is imperative to valorize by incorporating them in feed of grasscutter. For this, we have proposed to produce three types of pellets based from green fodders and/of products and by-products of maize and other food ingredients and evaluate their influences on growth performance of grasscutter in captivity. Research assumptions are: (i) the pellet 1 consists of green fodders, products and by-products maize and other food ingredients is the most consumed by livestock aulacodes (ii) grasscutter fed with pellets externalize good growth performance (iii) grasscutter fed with the pellet 1 express the best performance.

\section{Materialsand Methods:- \\ Study site:--}

The experiment was conducted in a grasscutter place of rearing of Non-Conventional Animal Species Breeding SubProgramm (S-PEEANC) of Zootechnical Veterinary and Halieutic Research Laboratory (LRZVH) in Agricultural Research Centre of Agonkanmey (CRA-Agonkanmey) in National Institute of Agricultural Research of Benin (INRAB) located in Commune of Abomey-Calavi.The climate is type Guinean, with two dry seasons (midNovember to mid-March and mid-July to mid-September) and two rainy seasons (mi-March to mi-July and miSeptember to mi-November). The average rainfall is $1.200 \mathrm{~mm}$ per year and average monthly temperatures vary between 27 and $31^{\circ} \mathrm{C}$ with relative humidity fluctuates between $65 \%$ from January to March and $97 \%$ from June to July. The monthly average was between 27 and $31^{\circ} \mathrm{C}$ with a deviation of $3.2^{\circ} \mathrm{C}$ between the hottest month (March) and the least hot (August).

\section{Animal material, measurement and infrastructures:-}

27 experimental bred grasscutter aged 7 months were used, divided into three groups with a live weight of $1928.4 \pm$ $51.99 \mathrm{~g} ; 2286 \mathrm{~g} \pm 59.52$ and $46.05 \pm 2077.6 \mathrm{~g}$ respectively. The enclosures of rectangular shaped stage 3 levels were used for the conduct of grasscutters. Communicated with a square opening of $0.2 \mathrm{~m}$ square drilled in a median wall and on the floor. This opening allowed the free passage of grasscutter from one compartment to another. For the experiment, the communication openings of the enclosure were closed by bricks to isolate animals. Each enclosure was equipped with feeder and waterer.A scale weighing of accuracy of brand Kitchen with reach $5 \mathrm{~kg}$ and of accuracy $1 \mathrm{~g}$ and peson ordinary of capacity $10 \mathrm{~kg}$ (50 g scale) of accuracy 1/500 were also used for weighing different samples.Brooms and shovels were used for cleaning of enclos and aulacoderie.

\section{Production of pellets:-}

After picking, the fodders were cut, dried in the shade.These fodder plants were crushed at the mill. Other food ingredients including maize grain, wheat bran, rice bran, cassava chips, cottonseed meal, soybean meal, the oyster shells and salt were also crushed. All forages and concentrates are placed in a blender to have a homogeneous mixture. The resulting mixture was then placed in an extruder to effect granulation. Three pellets were produced for 
testing.The pellet 1 consisted of green fodders and food supplements, the pellet 2 consisted of products and byproducts maize and the pellet 3 consisted of green fodders, food supplements and medicinal plants.The proportion and the quantity of ingredients used in the formulas are shown in Table 1.

Table 1:- Amount of ingredients for $100 \mathrm{~kg}$ of pellets

\begin{tabular}{|l|c|c|c|}
\hline \multirow{2}{*}{ Food Ingrédients } & \multicolumn{3}{|c|}{ Proportion of pellets (\%) } \\
\cline { 2 - 4 } & Pellets 1 & Pellets 2 & Pellets 3 \\
\hline Guinea Grass & 5,00 & - & 5,00 \\
\hline Ocimumgratissimum & - & - & 5,00 \\
\hline Ocimum basilicum & - & - & 5,00 \\
\hline Vernonia amygdalina & - & - & 5,00 \\
\hline Elephantgrass & 5,00 & - & - \\
\hline Paspalumvaginatum & 5,00 & - & - \\
\hline Leucaenaleucocephala & 3,00 & 4,00 & 3,00 \\
\hline Moringaoleifera & - & 4,00 & - \\
\hline Imperatacylindrica & - & - & - \\
\hline Papayaseeds & & & 16,00 \\
\hline Maize grain & 30,00 & 28,50 & 20,00 \\
\hline Maize bran & 18,00 & 30,00 & 15,00 \\
\hline Maizeflour & - & 14,00 & - \\
\hline Rice bran & 8,00 & 10,00 & 8,00 \\
\hline wheat bran & 8,00 & - & 8,00 \\
\hline Cotton cake & 8,00 & - & 8,00 \\
\hline Soyabeanmeal & 8,00 & - & - \\
\hline Maize spathe & - & 7,50 & - \\
\hline Cassavaroot & - & - & - \\
\hline Oyster shellpowder & 1,50 & 1,50 & 1,50 \\
\hline Salt & 0,50 & 0,50 & 0,50 \\
\hline Total & 100 & 100 & 100 \\
\hline
\end{tabular}

\section{Experimental conditions:-}

The 27 grasscutters were divided into three groups of nine (09) grasscutters and divided into three under-groups of three grasscutters. The experimental device was a randomized complete block with three treatments (pellets) repeated three times.The nine under-groups were considered units of observation. Each block has received three rations because of a ration by subgroup in the block.After their repartition in under-group, grasscutters underwent dietary transition of ten (10) days following the recommendations made by Mensah and Ekué (2003).Food distribution is done once in the morning between 7 and 8 hours. Water was served at will in the trough and renewed every day. Every day the foods are weighed before the service. The next day after cleaning the pens, the refus are rid of feces and weighed.

\section{Determination of parameters zootechnical:-}

Parameters such as average weight gain, average daily gain, feed consumption ratio and daily food consumption were determined at the end of the experiment. The formulas used are shown in Table 2

Table 2: Formulas used to determine the parameters zootechnical

\begin{tabular}{|l|l|l|}
\hline Parameterszootechnical & \multicolumn{1}{|c|}{ Formulas } & \multicolumn{1}{c|}{ Observations } \\
\hline Averageweight gain & $\mathrm{GPM}=\mathrm{Pf}-\mathrm{Pi}$ & Pi $:$ initial weight; Pf $:$ finalweight \\
\hline Averagedaily gain & $\mathrm{GMQ}=\mathrm{GPM} / \mathrm{N}$ & $\mathrm{N}:$ number of days GPM $:$ average weight gain \\
\hline Daily foodconsumption & $\mathrm{CAQ}=\mathrm{Qs}-\mathrm{Qr}$ & $\mathrm{Qs}:$ quantity of food served $\mathrm{Qr}:$ quantity of food refuse \\
\hline Feedconsumption ratio & $\mathrm{IC}=\mathrm{Qi} / \mathrm{GPM}$ & $\mathrm{Q}$ : $:$ quantityof food ingested \\
\hline
\end{tabular}

Laboratory analysis of the pellets:-

Food samples offered and rejected of different pellets were collected and analyzed using the methods allowed by the Interprofessional Office of Analytical Studies (BIPEA, 1976) and Association of Official Analytical Chemist (AOAC, 2000). These analyzes were performed at Laboratories of Sciences of sol Water and Environment (LSSEE)in Agricultural Research Centre of Agonkanmey (CRA-Agonkanmey) in National Institute of Agricultural Research of Benin (INRAB) and Laboratory of Sciences and Animal Production Techniques of the Faculty of 
Agricultural Sciences (FSA) of University of Abomey-Calavi (UAC). The Determination of dry matter (DM) was made by drying by placing in an oven at $105^{\circ} \mathrm{C}$ for $24 \mathrm{~h}$ to stabilize the weight and then weighed after it has cooled. This is for remove any residual water. The determination of the crude protein content was made by the method Kjeldahl (AOAC, 2000), the crude fiber by the method of Van Soestet al. (1991), the fat was determined by the Soxhlet device (AOAC, 2000) and that of crude ash by carbonization slow at oven. The contents of calcium and phosphorus are assayed by atomic absorption spectrophotometry. The analysis of each chemical element was repeated twice.

Data statistical analysis:-

Descriptive statistics was conducted in terms of mean and standard deviation for the data.The normality test ofRoyan- Joiner and the test of equality of variances were performed for test respectily the normality and equal variances.In the case of normality, an analysis of variance (ANOVA) was performed for the zootechnical parameters. Otherwise, the non-parametric test Kuskal-Wallis was performed at threshold $5 \%$.The separation of averages was carried from the Tukey test at threshold 5\%.The analyzes were performed with the R3.0.2 software (R Development Core Team. 2012.http://www.Rproject.org/).The different curves were carried out with Excel 2010.

\section{Results:-}

\section{Nutritional values of pellets:-}

The bromatological analysis of three pellets gives the values of the nutrients shown in Table 3 . The dry matter content and the fat matter of the three pellets were not significantly different ( $>>0.05)$. As against the organic matter and total carbon was significantly different for the three pellets $(\mathrm{p}<0.05)$, as well as that of crude protein, crude fiber, total ash, Calcium and phosphorus for the three pellets $(\mathrm{p}<0.05)$.

Table 3: Chemical composition of pellets

\begin{tabular}{|c|c|c|c|c|}
\hline \multirow{3}{*}{ Parameters } & \multicolumn{3}{|c|}{ Chemical composition of pellets } & \multirow{3}{*}{ Prob } \\
\hline & Pellet 1 & Pellet 2 & Pellet 3 & \\
\hline & Average \pm ET & Average \pm ET & Average $\pm \mathrm{ET}$ & \\
\hline Dry matter (\%) & $90.04 \pm 0.09$ & $90.33 \pm 0.03$ & $90.33 \pm 0.03$ & 0.1637 \\
\hline Organicmatter (\%DM) & $93.34 \pm 0.02 b$ & $94.05 \pm 0.03 a$ & $92.75 \pm 0.01 \mathrm{c}$ & $5.88 \mathrm{e}-07$ \\
\hline Crudeprotein $(\% \mathrm{DM})$ & $17.59 \pm 0.02 \mathrm{a}$ & $10.73 \pm 0.01 \mathrm{c}$ & $14.09 \pm 0.02 b$ & 0.01556 \\
\hline Crude fibre (\%DM) & $9.02 \pm 0.12 \mathrm{a}$ & $7,23 \pm 0.16 c$ & $8.21 \pm 0.14 b$ & 0.01556 \\
\hline Crude fat $(\% \mathrm{DM})$ & $2.16 \pm 0.10$ & $2.09 \pm 0.03$ & $2.27 \pm 0.04$ & 0.26987 \\
\hline Total ash (\%DM) & $6.66 \pm 00 b$ & $5.95 \pm 0.01 c$ & $7.25 \pm 0.01 \mathrm{a}$ & 0.01455 \\
\hline Total carbon $(\% \mathrm{DM})$ & $46.67 \pm 00 b$ & $47.02 \pm 0,01 a$ & $46.38 \pm 0.01 \mathrm{c}$ & $2.76 \mathrm{e}-11$ \\
\hline Calcium (\%DM) & $0.64 \pm 0.02 \mathrm{c}$ & $0.88 \pm 00 \mathrm{~b}$ & $0.95 \pm 0.02 a$ & 0.01455 \\
\hline Phosphorus (\%DM) & $0.42 \pm 0.01 \mathrm{a}$ & $0.33 \pm 0.03 b$ & $0.47 \pm 0.02 \mathrm{a}$ & 0.00738 \\
\hline
\end{tabular}

ET = Error-Type. Values followed by different letters $(a, b, c)$ on the same line are significantly different according to Tukey's test at the threshold $5 \%$. Prob = Probability.

\section{Weighting growth of grasscutters experimental fed with pellets:-}

The Body average live weight of grasscutters fed with pellet 1 during the experiment ranged from 1928,4 $\pm 51.99 \mathrm{~g}$ à $2865.6 \pm 63.96 \mathrm{~g}$ and that of grasscutters fed the pellets 2 ranged from $2286 \pm 59,52 \mathrm{~g}$ à $2818,8 \pm 134,2 \mathrm{~g}$.In the grasscutters fed with pellet 3 , average weight ranging from $2077.6 \pm 46.05 \mathrm{~g}$ à $2832.6 \pm 93.73$ gwas recorded. The increase in body average weight was continuous in the grasscutters fed with three pellets. The difference was significant between the average weight of animals fed with three pellets from start to week $6(\mathrm{p}<0.05)$. By cons of the 8th week until the end the difference was not significant ( $p>0.05$ ).

Table 4:- Variation bi-weekly of weights live body of grasscutters

\begin{tabular}{|l|l|l|l|l|}
\hline \multirow{3}{*}{$\begin{array}{c}\text { Périod } \\
\text { (Weeks) }\end{array}$} & \multicolumn{3}{|c|}{ Variation of weights of grasscutters en $\mathrm{g}$} & \multirow{2}{*}{ Prob } \\
\cline { 2 - 4 } & \multicolumn{1}{|c|}{ Pellet 1 Pellet 2 } & \multicolumn{1}{|c|}{ Pellet 3 } & \\
\hline Week 0 & Average \pm ET & Average \pm ET Average \pm ET & 0.001902 \\
\hline Week 2 & $1928.4 \pm 51.99 \mathrm{~b}$ & $2286 \pm 59.52 \mathrm{a}$ & $2077.6 \pm 46.05 \mathrm{~b}$ & 0.002753 \\
\hline Week 4 & $2984 \pm 49.53 \mathrm{~b}$ & $2329.5 \pm 61.01 \mathrm{a}$ & $2129.6 \pm 49.17 \mathrm{~b}$ & 0.00538 \\
\hline Week 6 & $2191.1 \pm 47.16 \mathrm{~b}$ & $2392.1 \pm 67.65 \mathrm{a}$ & $2208.4 \pm 53.79 \mathrm{ab}$ & 0.0364 \\
\hline Week 8 & $2331 \pm 47.38$ & $2464 \pm 78.85 \mathrm{a}$ & $2314.3 \pm 62.25 \mathrm{ab}$ & 0.13 \\
\hline Week 10 & $2498,2 \pm 49.77$ & $2541.4 \pm 92.56$ & $2452.8 \pm 75$ & 0.151 \\
\hline Week 12 & $2865.6 \pm 63.96$ & $2634.1 \pm 109.01$ & $2620.3 \pm 86.64$ & 0.594 \\
\hline
\end{tabular}


ET $=$ Error-Type. Values followed by different letters $(a, b)$ on the same line are significantly different according to Tukey's test at the threshold $5 \%$. Prob $=$ Probability.

\section{Performance of grasscutters fed with three pellets during the experiment:-}

The results show that average daily gain is $(10.41 \pm 0.24 \mathrm{~g} /$ day $)$ in grasscutters fed with the pellet $1,(5.92 \pm 1.06$ $\mathrm{g} /$ day) for grasscutters fed with pellet 2 and $8.39 \pm 0.73 \mathrm{~g} /$ day in the grasscutters fed with pellet 3 (table 5). The difference was significant between average daily gain of grasscutters fed with three pellets $3(\mathrm{p}<0.05)$. It is the same for the weight change $(p<0.05)$ and daily food consumption $(p<0.05)$. The average consumption indices recorded during the experiment ranged from $0.066 \pm 0.018$ to $0.083 \pm 0.008$ with a significant difference $(p<0.05)$.

Table 5: Performance of grasscutters fed with three pellets

\begin{tabular}{|l|c|c|c|c|}
\hline \multirow{2}{*}{ Parameters } & Pellet 1 & Pellet 2 & Pellet 3 & \multirow{2}{*}{ Prob } \\
\cline { 2 - 4 } & Average \pm ET & Average \pm ET & Average \pm ET & \\
\hline Averageinitial weight $(\mathrm{g})$ & $1928.4 \pm 51.99 \mathrm{~b}$ & $2286 \pm 59.52 \mathrm{a}$ & $2077.6 \pm 46.05 \mathrm{~b}$ & 0.001902 \\
\hline Averagefinal weight $(\mathrm{g})$ & $2865.6 \pm 63.96$ & $2818.8 \pm 134.2$ & $2832.6 \pm 93.73$ & 0.594 \\
\hline Weight variation $(\mathrm{g})$ & $937.2 \pm 21.58 \mathrm{a}$ & $532.80 \pm 95.41 \mathrm{c}$ & $755 \pm 66.06 \mathrm{~b}$ & $7.82 \mathrm{e}-05$ \\
\hline Average daily gain $(\mathrm{g} /$ day) & $10.41 \pm 0.24 \mathrm{a}$ & $5.92 \pm 1.06 \mathrm{c}$ & $8.39 \pm 0.73 \mathrm{~b}$ & $7.82 \mathrm{e}-05$ \\
\hline Daily foodconsumption(g) & $62.29 \pm 1.80 \mathrm{a}$ & $44.22 \pm 1.97 \mathrm{c}$ & $56.39 \pm 1.91 \mathrm{~b}$ & $3.4 \mathrm{e}-09$ \\
\hline Food consumption indices & $0.066 \pm 0.02 \mathrm{c}$ & $0.083 \pm 0.01 \mathrm{a}$ & $0.075 \pm 0.01 \mathrm{~b}$ & 0.001455 \\
\hline
\end{tabular}

ET $=$ Error-Type. Values followed by different letters $(a, b, c)$ on the same line are significantly different according to Tukey's test at the threshold $5 \%$. Prob = Probability.

\section{Bi-weekly average weight gain in of grasscutters fed with three pellets:-}

Figure 1 show the performance of growth in of grasscutters experimental fed with three pellets. An average weight gain increase was noted in the second week until the end of the experiment. From start to 8th week, the growth was similar for grasscutters fed the pellets 1 and 3. But of the 8th week at the 12th week, a more pronounced growth was observed in animals fed with the pellet 1.From the 4th week until the end of the experiment, the grasscutters fed with pellet 2 have expressed of weight gains less significant than the grasscutters fed the pellets 1 and 3 except for the 10th week where the means weight gain registered in the grasscutters fed with pellets 2 and 3 were similar.

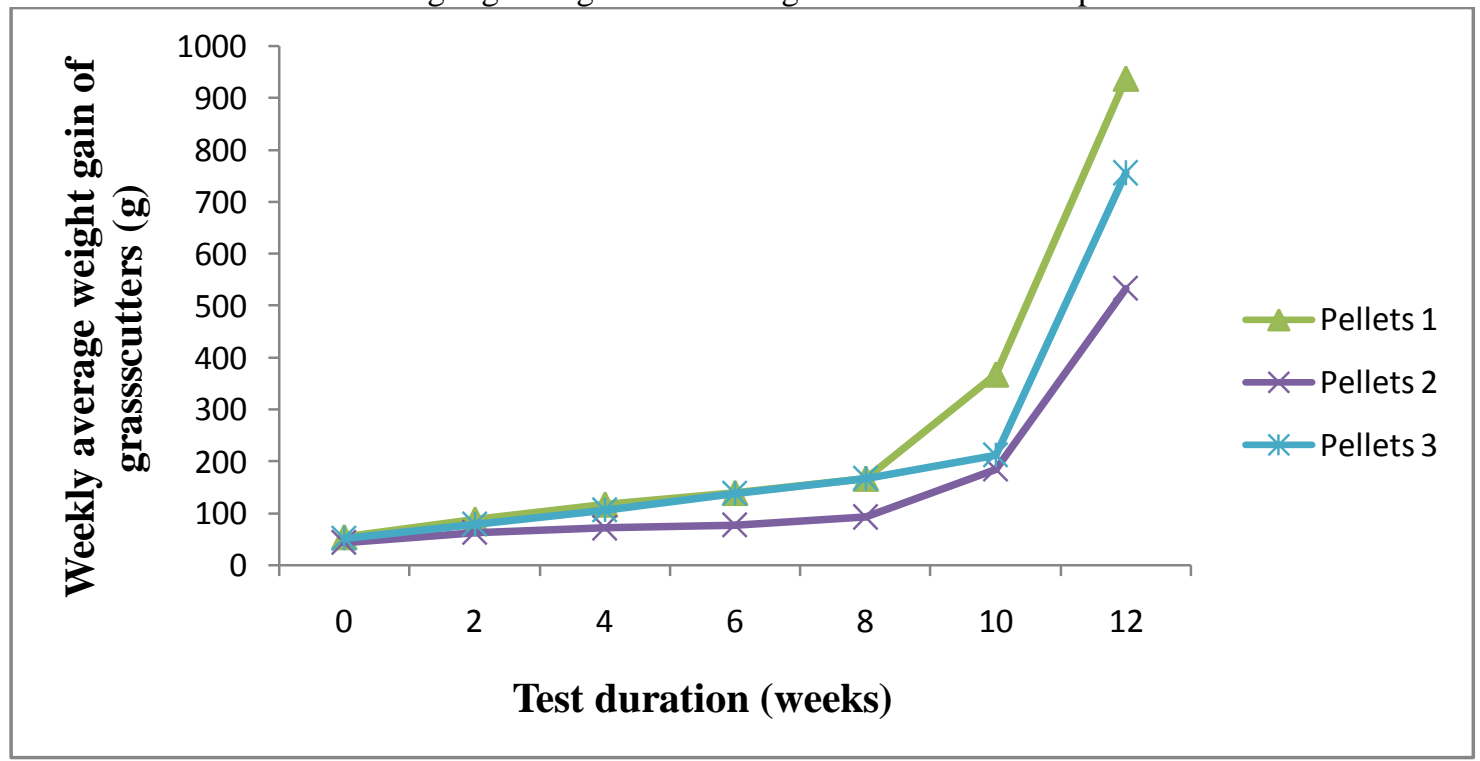

Figure 1:- Average weight gain of grasscutters fed with three pellets

Average food consumption bi-weekly in the experimental grasscutters:-

Figure 2 shows the evolution of the average bi-weekly food consumption the grasscutters fed with three pellets.Minimum average food consumption of $39.13 \pm 3.92 \mathrm{~g}$ and $53.78 \pm 2.38 \mathrm{~g}$ was obtained between 0 and 14th day of the experiment respectively for the pellet 2 , and the pellet 3 and $58.07 \pm 2.68 \mathrm{~g}$ for pellet 1 between 15 th and 29th day.Average maximum values of the food consumption of $66.17 \pm 2.78 \mathrm{~g}$ and $58.18 \pm 2.20 \mathrm{~g}$ respectively for the pellet 1 and 3 were obtained between the 45th and the 59th day against $50.75 \pm 192 \mathrm{~g}$ for the pellet 2 between the 
75th and the 90th day.A change was noted in the average food consumption in animals for experimentation. The grasscutters have eaten more the pellet 1 and the pellet 3 that the pellet 2 (Figure 2).

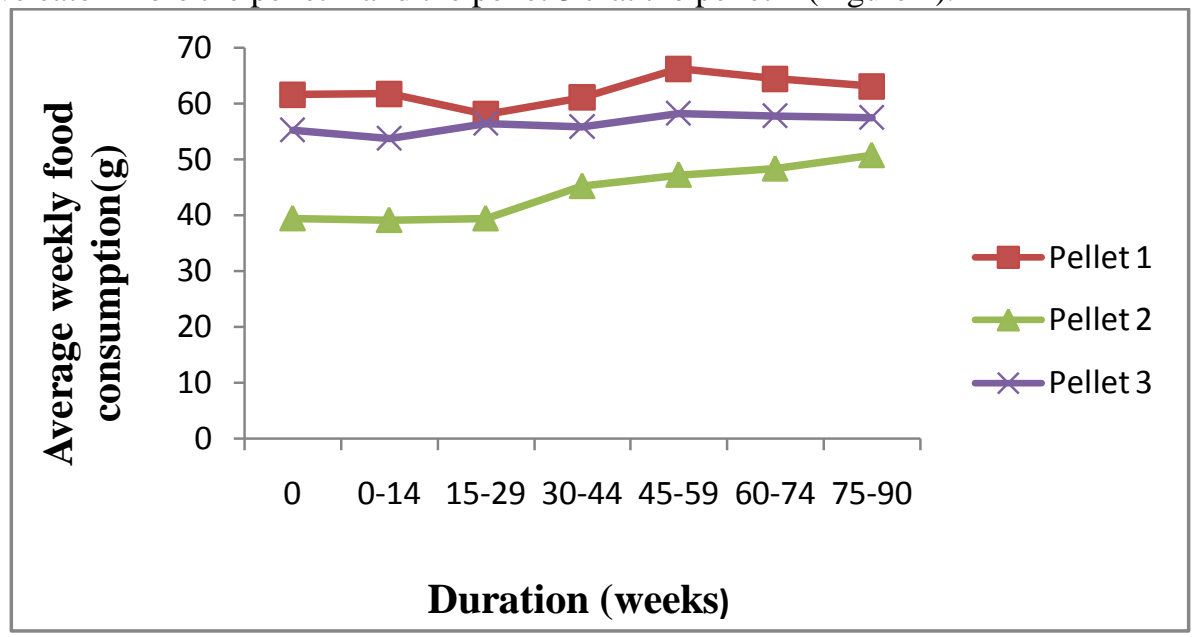

Figure 2:- Average food consumption of grasscutters fed with pellets

Average food consumption and weight gain means biweekly in animals fed with three pellets:-

Figures 3, 4 and 5 indicate food consumption and weight gain in of grasscutters fed with three pellets.Despite the fluctuations observed in the average food consumption of three pellets in animals during the test, they had induced an increase in continuous average weight gain from start to end of the experiment.The average weight gain in the grasscutters fed with three pellets was greater between the 8th and 12th week with an average food consumption varies relatively little during this period.

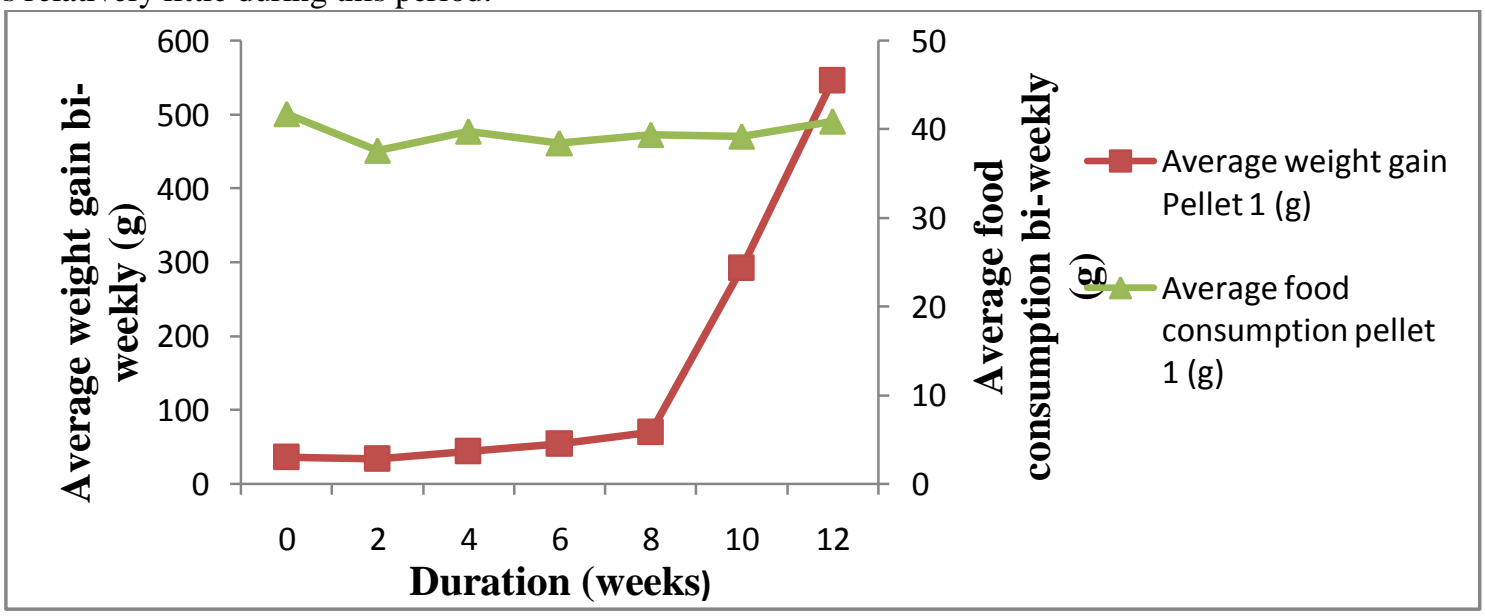

Figure 3:- Food consumption and bi-weekly weight gain of grasscutters fed with the pellet 1 


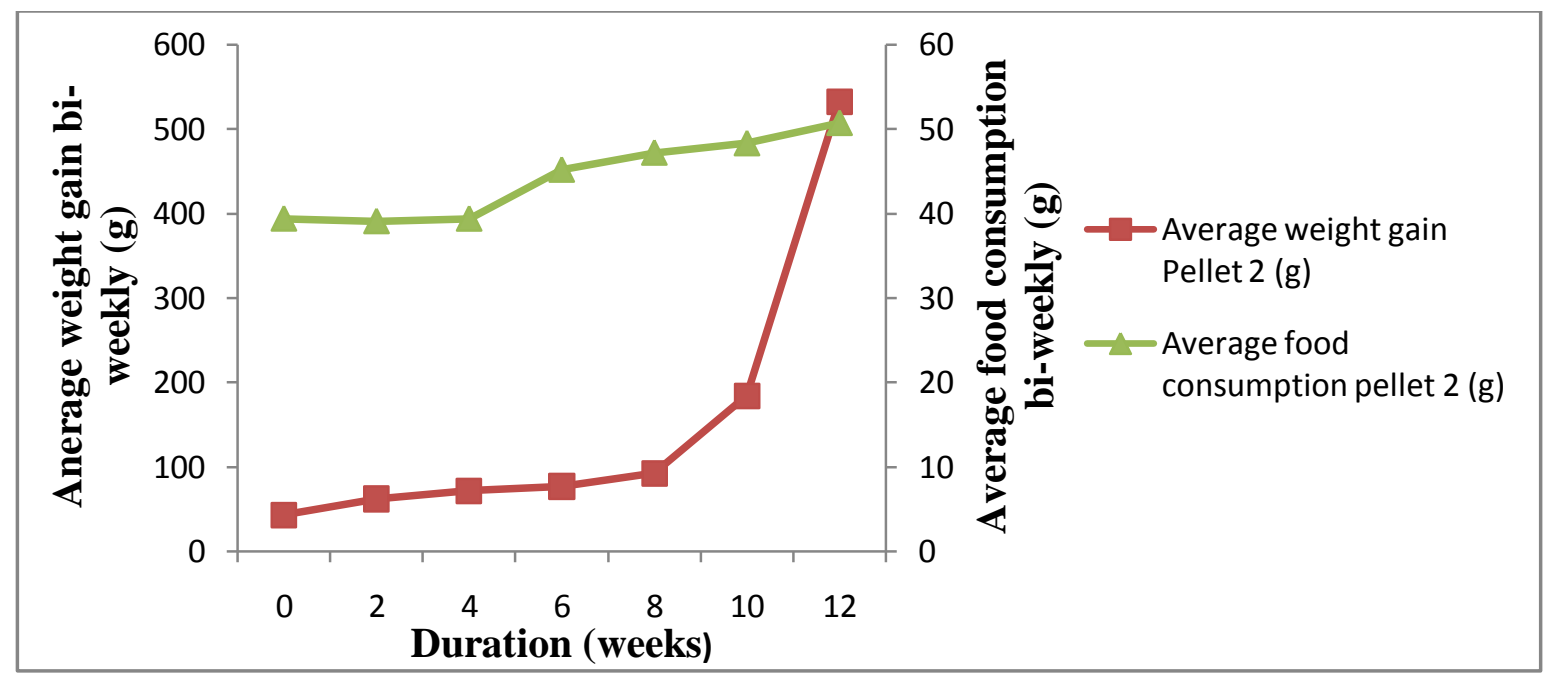

Figure 4:- Food consumption and bi-weekly weight gain of grasscutters fed with the pellet 2 .

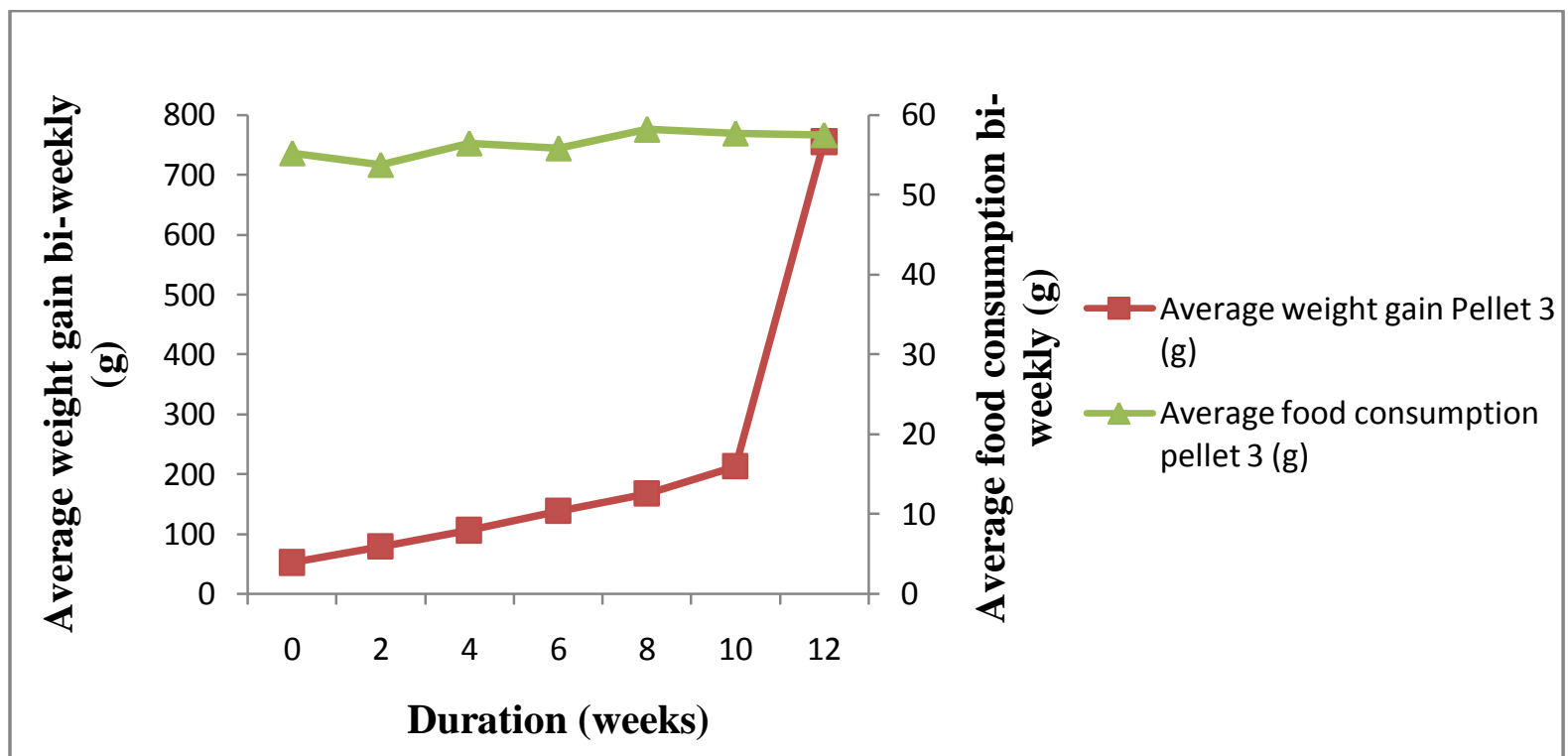

Figure 5:- Food consumption and bi-weekly weight gain of grasscutters fed with the pellet 3

\section{Discussion:-}

Nutritional values of pellets:-

The chemical composition of the pellets produced and used in this study can be compared to those found in the literature. The values of the dry matter of the pellets obtained (90.04 to $90.33 \%$ ) are similar to those obtained (90.92 to $91.25 \%$ ) by Wogar (2012).They are superior to the values ranging from: 83.3 to $88.5 \%$ (Fantodjiet al., 2003); 76.37 to 89.15 (Traoreet al., 2009); 86.65 (Wogar and yara, 2015); 80.7 to $89.49 \%$ (Soroet al, 2014); 85 to 88.50 (Seiduet al., 2016).But these values are lower than those ranging between 94-97 \% (Okeke and Mogbo 2013). The organic matter content varying between 92.75 and $94.05 \%$ are similar to those reported by Traore et al. (2008), Traoreet al. (2009) and Ngoulaet al. (2012).

The crude protein obtained in this study for pellets 1 and 3 (14.09 and 17.59\%) are within the range from 12 to 18.5 $\%$ and 14-18 \% dry matter recommended for grasscutters (Mensah, 1993; Mensah, 1995; Adeniji, 2009).The contents of crude protein of pellets 1 and 3 obtained in this study belong to the interval: 11.5 to $20.2 \%$ (Traoreet al., 2009); 11.62 to $20.20 \%$ (Wogaret al., 2013).All protein values found for the three pellets are in the range from 9.6 to $24.5 \%$ (Fantodjiet al., 2003); 10.45 to 21.90 (Wogar and Ayuk 2012).However, these values are lower than the intervals from 20.88 to 22.98 (Okeke and Mogbo, 2013) and from 17.90 to $20.6 \%$ (Seiduet al., 2016). The levels of 
fiber (from 7.23 to $9.02 \% \mathrm{DM}$ ) obtained in the course of our work are in the interval from 6.70 to $18.56 \%$ obtained by Ngoulaet al. (2012); 4.35 to $21.45 \%$ reported by Wogar (2015).These values are higher than values : 6.01 to 6.26 $\%$ and from 3.99 to $4.52 \%$ obtained respectively by wogar (2012) and Okerekeet al. (2015). They are also less than 13.23 to $17.90 \%$ found by wogar (2011); 11-21 (Okeke and Mogbo, 2013) and from 16.67 to 19.79\% (Seiduet al., 2016). The values (5.95 to 7.25\% DM) total ash found in this study belong to the interval 6-9 \% reported by Seiduet al. (2016). They are similar to 3.29 to $7.09 \%$ found by Ngoulaet al. (2012). These values are less than 8.68 to 10.33 \% (Traoreet al., 2009); 11.75 to $11.87 \%$ (Wogar and Ayuk, 2012) and 25-35\% (Okeke and Mogbo, 2013).The calcium content (0.64 to $0.95 \%$ ) obtained in this study are similar to 0.35 to $0.9 \%$ (Schrage and Yewadan, 1999); 0.2-0.7 \% (Pond et al., 1995); 0.32 to $0.66 \%$ (Traoreet al., 2009); 0.71 (Soroet al., 2014); 0.82 to $0.85 \%$ (Seiduet al., 2016). They belong to the interval 0.058 to $1 \%$ reported by Ngoulaet al. (2012).Phosphorus levels (0.33 to 0.47 $\%$ ) found in this work is in agreement with values from 0.26 to $0.42 \%$ (Traoreet al., 2009) and 0.3 to $0.33 \%$ (Seiduet al., 2016). They are less than 0.53\% (Soroet al., 2014).Fat contents (2.09 to $2.27 \%$ DM) obtained for the pellets are between 2.5-4.5 \% recommended (Mensah, 1993; Mensah, 1995). They are also consistent with those reported by Soroet al. (2014) and Traoreet al. (2009).But these values are less than 8.02 to $8.82 \%$ (Okeke and Mogbo, 2013). The differences noted in the various nutrients between this study and the various works cited can is due to the quality and quantity of various food ingredients used in food composition.

\section{Gain variation of body average weight of grasscutters:-}

The average total weight gain obtained in the grasscutters fed with the pellet $2(532.80 \pm 95,41 \mathrm{~g})$ belongs to the range 225-625 g (Annoret al., 2008) at Ghana in the grasscutters at the end of a 24-week study and 400-810 $\mathrm{g}$ (Fantodjiet al., 2003). That obtained in the grasscutters fed with pellets 3 is in the range 400-810 g (Fantodjiet al., 2003) in a study Impact of Brewery refuse and Leucaenaleucocephala as food supplement on Cane Rat growth under breeding conditions. Similarly, the average weight gain recorded in of grasscutters fed with the pellets (937.2 \pm $21.58 \mathrm{~g}$ ) belongs to the interval from 650 to $1190 \mathrm{~g}$ obtained by Karikari and Nyameasem(2009) in study Productive Performance and Carcass Characteristics of Captive Grasscutters (Thryonomys swinderianus) Fed Concentrate Diets Containing Levels of Guinea Grass; 880-1175 g obtained by Ngoulaet al. (2012) the effects of feed supplementation period on some reproductive parameters of female cane rats (Thryonomys swinderianus) at Cameroun; 896.82 to $1007 \mathrm{~g}$ in of grasscutters fed with different types of pellets (Okeke and Mogbo, 2013) and et 937.18 to $1145.13 \mathrm{~g}$ obtained by UwalakaandAhaotu(2013).All values obtained for average weight gains recorded in grasscutters fed with pellets $(532.80 \pm 95.41$ to $937.2 \pm 21.58 \mathrm{~g})$ are similar to (579-1029 g) reported by Etchuet al. (2012) in comparative performance of grasscutters (Thryonomys swinderianus) fed maize and rodent pellets as concentrate supplement under intensive management system in Cameroon.However, these values are below the intervals 1024 to $1121 \mathrm{~g}$ reported by Obi et al. (2008)in one study where performance in grasscutters fed with four different kinds of conventional fodder are assessed; 1466.4 to $2040.42 \mathrm{~g}$ in males and 1348.17 to $1685.85 \mathrm{~g}$ in females obtained by Soroet al. (2014) in Contribution of young grasscutter (Thryonomys swinderianus) feeding after weaning in Côte d'Ivoire and 1780 to $2100 \mathrm{~g}$ reported by Seiduet al. (2016) in study growth performance of grasscutters (Thryonomys swinderianus) in captivity fed on pelleted forage and cassava Tubers with the peel in Ghana.The difference in average weight gain observed between the values found in this study and those reported by various authors may be the result of differences in chemical quality including the difference between the protein levels in the various food used.For Increased body weight may be associated with high levels of protein in the diet. And the protein content influences the amount of food consumed by herbivores (Minson, 1997). This is consistent with our results. Similar observations were made with of grasscutters (Annoret al., 2008; Pokuet al., 2013).

\section{Average daily gain grasscutters:-}

The values of the average daily gains obtained from grasscutters fed with pellets $(5.92 \pm 1.06$ to $10.41 \pm 0.24 \mathrm{~g} / \mathrm{day})$ belongs to the interval $4.8-11.2 \mathrm{~g} /$ day (Mensahet al., 2001; Mensahet al., 2005)when the animals are fed with fresh panicum maximum supplemented with of concentrates a protein rate between 12-17 \%; 4.19 to $14.64 \mathrm{~g} / \mathrm{day}$ (Fantodjiet al., 2003).Average daily gain obtained from grasscutters fed with the pellets 3 is in the range 2.68 to 7.44 g/day (Annoret al., 2008).Similarly, the average daily gain noted in grasscutter fed with the pellet 3 (8.39 g/day) and with the pellet 1 (10.41 g/day) belong to the ranges 8.8 to $12.1 \mathrm{~g} /$ day obtained by Schaible (1970);7.22 to 8.75 reported by Ikpeze and Ebenebe (2004) in a study on the reproductive performance of the various housing system of grasscutters; 7 to $12 \mathrm{~g}$ /day found by Mensah and Okeyo (2005) in both sexes of male and female of the grasscutters and 7.85 to $10.49 \mathrm{~g} /$ day obtained by Ngoulaet al.(2012).Average daily gain obtained from grasscutters fed with the pellet 1 (10.41 g/day) belong to ranges from 9.03 to $11.20 \mathrm{~g} /$ day obtained by wogar and yara (2015) and from 9.97 to $10.65 \mathrm{~g} /$ day reported by Seiduet al. (2016). But all the values found in this study are lower than $14.68 \pm 1.07$ for two sex obtained by Soroet al. (2014) and higher 3.31 to 4,97g/day reported by Kenfacket al. (2006). 


\section{Daily food consumption of grasscutters:-}

Daily food consumption $(62.29 \mathrm{~g})$ recorded in the grasscutters fed with pellet 1 and $56.39 \mathrm{~g}$ noted in grasscutters fed with the pellet 3 belong to the interval from 47.30 to $69.40 \mathrm{~g} /$ day found by Wogar and yara (2015). All the daily food consumption (44.22 to $62.29 \mathrm{~g}$ ) of the pellets obtained in this study situate in the range from 35.7 to $132.4 \mathrm{~g} \mathrm{DM} / \mathrm{kg}$ LW obtained by Traoreet al. (2009).But all values are below the ranges 150-250 $\mathrm{g}$ found by Mensah (1995); 74.36 to $99.32 \mathrm{~g}$ obtained by Okeke and Mogbo (2013) and from 87.67 to $88.65 \mathrm{~g}$ reported by Seiduet al. (2016) and greater than 23.80 to 36.95 g noted by Fantodjiet al.(2003). The difference observed for the daily food consumption during this study and cited works may be due to the chemical composition of feed and the physical form of food presentation.The increase in crude fiber in the diet cause the decreased of food consumption (Etchuet al., 2012); which is in agreement with the results obtained in this study. The increase in fiber content in feed rations of grasscutters may be associated with a decrease in the digestibility of dry matter, protein and fat in dominant animals and a reduction in the growth rate (Van Zylet al., 1999).

\section{Food consumption conversion ratios:-}

Food consumption aims to meet the food needs and get better growth and better production in animals (Traoreet al., 2009).This is best reflected by the food consumption index that varies among the grasscutters as already mentioned Mensah (1995).The consumption index values obtained in this study are in the range 0.043 to 0.12 found by Fantodjiet al. (2003). They are better than values 43.24 to 119.38 obtained by Annoret al.(2008);1.66 to 3.52 reported by Wogaret al. (2007); 1.81 and 6.95 found by Henry and Njume (2008); 4.86 to 5.04 reported by Obi et al. (2008) ; 4.8 and 7.5 obtained by Nyameasem and Karikari (2009); 19.5 to 98.56 noted by Henry et al. (2012); 15.33 to 17.76 reported by Okeke and Mogbo (2013); 11.92 to 15.93 obtained by Uwalaka and Ahaotu (2013);8.35 \pm 0.35 for the male; $10.16 \pm 1.17$ to $9.26 \pm$ for female and 0.87 both sexes found by Soroet al. (2014) reported at the grasscutters in different studies. The difference between food consumption indices obtained in this study and those reported by various authors cited may be due to physiological stage of grasscutters used in the experiments and the physical form of food presentation. Similar observations were made by Traoreet al. (2009).

\section{Conclusion:-}

The objective of this study is to formulate the pellets based green fodder and/or of products and by-products of maize and other food ingredients to evaluate the zootechnical performance of grasscutters fed with the pellets. At the end of our work the results show that the grasscutters can be fed with pellets made based green fodders and products and by-products of maize with the externalization of good zootechnical performance. The best performance are recorded in grasscutters fed with the pellets 1 and 3 based from green fodders, products and by- products of maize and other food ingredients compared to the grasscutters fed with pellets 2 based from products and by-products of maize. The pellets 2 can be used in grasscutters breeding to feed in all seasons the grasscutters thus settling the thorny problem of affouragement fodder in all seasons, reducing the breeding driving time and allow better extérioration of zootechnical performance of grasscutters breeding.

\section{Acknowledgements:-}

We thank the authorities of the National Institute of Agricultural Research of Benin (INRAB) for allowing the work we were doing in the center.We also thank the Framework Programme to Support Agricultural Diversification (ProCAD) through the Agricultural Productivity Programme in West Africa (WAAPP) for financial support. 


\section{References:-}

1. Adéniji, A.A.(2009): Protein and Energy Requirements of Weaner Grasscutters. Animal Nutrition and Feed Tech., 9: 73-79.

2. Aïzoun F.F., Pomalegni,S.C.B., Farougou,S., and Mensah,G.A.(2015):Literature review on feeding of grasscutter with of pellets of green fodders in Benin. ASA, 19(2): 389-400. 2015 ISSN 1669-5009. 12p.

3. Annor A.Y., Kagya-AgyeangJ.K., Abbam,J.E.Y., Oppong,S.K., Agoe,I.M. (2008):Growth performance of grasscutter (Thryonomys swinderianus) eating leaf and stem fractions of Guinea grass (Panicummaxmium). Livest. Res. Rural Dev., 20: 125.

4. A.O.A.C.(2000): Association of Official Analytical Chemist, Official Methods of Analysis 17th edition Washington D.C.

5. BIPEA.(1976):Bureau Interprofessionnel d'Etudes analytiques. Recueil des méthodes d'analyses des communautés Européennes : 2 route du port Charbonnier, 92230 Gennevilliers, 140p.

6. Etchu, K.A., Ndzi, V.N., Ndamukong, K.J., and Oben, B. (2012):Comparative performance of grasscutters (Thryonomys swinderianus) fed maize and rodent pellets as concentrate supplement under intensive management system in Cameroon. Afr. J Agric. Res., 7(6), pp. 883-891.

7. Fantodji, A., B.Traoré,etKouamé, L.P. (2003):Impact of Brewery refuse and Leucaenaleucocephala as food supplement on cane rat growth under breeding conditions. AgronomieAfricaine, 15(1): 39-50.

8. Henry,A.J.andNjume,G.N.(2008): Effect of varied energy levels on the carcass characteristics of grasscutters (Thryonomys swinderianus). Proceeding 33rd Annual Conference of Nigerian Society for Animal Production (pp. 168-170), Ogun State.

9. Henry, A.J., Ibe S.N., and Asuquo,B.O.(2012): Effect of weaning age on growth and slaughter characteristics of grasscutters (Thryonomys swinderianus) raised under intensive management in the humid tropics. J. Agr. Sci., 4(12): 232-246.

10. Ikpeze, O.O. and Ebenebe,C.I.(2004): Productive Performance of the Grasscutter (Rodentia: Thryomyidae) Reared under Tree Different Housing Systems. Bio-Research 2(2): 19-21.

11. Jori, F., Cooper,J.E.and Casa, J.I.(2001):Postmortem finding in captive cane rats (Thryonomys swinderianus) in Gabon. Veterinary Record 148: 624-628.

12. Karikari, P.K. and Nyameasem, J.K. (2009): Productive Performance and Carcass Characteristics of Captive Grasscutters (Thryonomys swinderianus) Fed Concentrate Diets Containing Varying Levels of Guinea Grass. World Appl. Sci. J. 6(4): 557-563.

13. Kenfack, A., Tchoumboué, J., Teguia, A.,Ngoula, F., Fuelefac Defang, H., Wadawa,S.andDougmo,A.(2007):Effects of early weaning and diet type on growth performances of cane rats (Thryonomys swinderianus) in captivity. Livest Res for Rural Dev. Volume 19, Article 39.

14. Mensah, G.A., Pomalegni, S.C.B.,AhoyoAdjovi, N.R.,Mensah, E.R., Guedou, M.S.E.,Koudande, O.D.(2013):Grass-cutter breeding: an alternative for food security and wildlife safeguarding in West Africa. RASPA Vol.11 NOS, 113-128.

15. Mensah, G.A.et Ekué,M.R.M.(2003) : L'essentiel en aulacodiculture. ReRE, KIT, IUCN, CBDDBénin/ ISBN: 99919-102-4-0, $160 \mathrm{p}$.

16. Mensah, G.A.(1993):Futteraufnahme und verdaulichkeitbeingrasnager (Thryonomys swinderianus). Thèse de doctorat. Institut 480, Université de Holenheim, Allemagne, 107 p.

17. Mensah, G.A.(1995) : Consommation et digestibilité alimentaire chez l'aulacode (Thryonomys swinderianus). Trop, 13 (3) : 123-124.

18. Mensah, G.A.(1997) : Ecoéthologie de l'aulacode Thryonomys swinderianus (Temminck, 1827) rongeur hystricomorphe élevé en captivité. In Actes du Séminaire National sur le Commerce International des reptiles capturés dans la nature et les dégâts causés aux cultures par les rongeurs à Cotonou, 24-28 Mars 1997, Bénin. Les Editions du Flamboyant-1999. ISBN : 2-909130-63-0.pp. 95-109.

19. Mensah, G.A., Pomalegni, S.C.B., Koudandé,O.D. (2005) : Fiche technique : Préparation artisanale de granulés de mélange de fourrage verts et d'ingrédients alimentaires concentrés pour nourrir des aulacodes d'élevage en toutes saisons. Dépôt légal N²997 du 30/11/2005, $4^{\text {ème }}$, trimètre 2005, Bibliothèque Nationale (BN) du Bénin. - ISBN : 99919-57-45-6. 1page Poster illustré en couleur, format A2, en bilingue : français et anglais.

20. Mensah,, G.A. and Okeyo, A.M. (2005): Continued Harvest of the Diverse African Animal Genetic Resources from the Wild through Domestication as a Strategy for Sustainable Use: Case of the Larger Grasscutter (Thryonomys swinderianus).

21. Mensah, G.A., Schwarzenberg, A.,Stier, C.-H.,Kangni, T., Gall, C.F.(1996): Aspects pratiques en élevaged'aulacodes (Thryonomys swinderianus). VI. Mesures préventives contre la mauvaise usure des incisives. Revue Elev. Méd. Vét. Pays Trop. 49 (4) : 341-346 
22. Mensah, G.A.(2000) : Présentation générale de l'élevage d'aulacodes, historique et état de la diffusion en Afrique. Actes Séminaire international sur l'élevage intensif de gibier à but alimentaire à Libreville (Gabon), Projet DGEG/VSF/ADIE/CARPE/UE, pp.45-59.

23. Mensah G.A., Gnimadji,A.,etHoungnibo,G.(2001) : Formulation d'un projet de promotion de la filière aulacode au Bénin, volume 1-Rapport principal : Diagnostic de la filière aulacode au Bénin, $116 \mathrm{p}$.

24. Minson, D.J.(1997): Ruminants: The Protein Producers. Biologist, 44: 463-464.

25. Ngoula, F.F., Ajiahoung K., Defang Fualefac, H., Kenfack, A., TéguiaA., and Tchoumboué,J.(2012): Effects of feed supplementation period on some reproductive parameters of female cane rats (Thryonomys swinderianus). Int. J. of Livest. Prod.vol. 3(7), pp. 78-82.

26. Obi, O.O., Omole, A.J.,Ajasin, F.O.,\&Tewe,O.O.(2008). Nutritive potentials of four conventional forages fed to growing grasscutter (Thryonomys swinderianus). Livest.Res. Rural Dev, 20 (179).

27. Okeke, J.J.\&Mogbo,T.C.(2013): Comparative stydy of growth performance of grasscutter fed on diverse foodstuff in captivity. I.J.A.B.R., 3(1) 2013: 85-89.

28. Okereke, C.O., Okereke, I.H., and Okiyi,P.C. (2015): Evaluation of the growth performance of grasscutter (Thryonomys swinderianus) fed diet containing varying levels of sweet potato rool meal and guinea grass (Panicum maximum). Nigerian Journal of Agriculture, Food and Environnement 11(3): 25-27.

29. Poku Jnr, P.A., Annor, S.Y., and Djang-Fordjour,K.T.(2013): Growth, Reproduction and Carcass Characteristics of Grasscutters (Thryonomys swinderianus) Fed on Different Levels of Protein Supplement. World J. of Zool., 8(2): 175-184.

30. Pomalegni, S.C.B., Babatounde, S.,GleleKakaï,L.R.,andMensah, G.A.(2015):Littérature review on feeding, food consumption and food digestibility of grasscutter (Thryonomys swinderianus). ASA19(2): 401-417, 2015. ISSN 1659-5009. 18p.

31. Pond, W.G., Church, D.C., and Pond, K.R.(1995):Basic Animal Nutrition and feeding (4 ${ }^{\text {th }}$ ed). John Wiley and Sons, Inc., New York.pp565-573.

32. R Core Team, (2012): R: A language and environment for statistical computing. R Foundation for Statistical Computing, Vienna, Austria.URL https://www.R-project.org/.

33. Schaible, P.K.(1970):Poultry nutrition. The AVL. Publishing Company Inc., Westops Connecticut. Pp289-299.

34. Schrage, R. and Yewadan, T. (1999): Raising Grasscutters, Deutsche Gesellschaft fur TechnischeZusammenarbeit (GTZ) Gmbh, Eschbom, Germany, pp. 99.

35. Seidu, J.M.., Dzisi, K.A., Addo, A.G., Barte-Plange, A., Odai, B. (2016) :Growth Performance of Grasscutters (Thryonomys swinderianus) in Captivity Fed on Pelleted Forage and Cassava Tubers with the Peel in Ghana. American Scientific Research Journal for Engineering, Technology, and Sciences, 2016, 18, $\mathrm{N}^{\circ} 1$, pp1-15.

36. Soro, S., Karamoko, Y.,Soro, D., Gonnety, T.J., Fantodji,A.(2014):Contribution of young grass-cutter (Thryonomys swinderianus) feeding after weaning. Les Technologies de Laboratoire, 8: 34.

37. Toleba, S.S., Mensah, G.A., Zougou, C.G.T., Codjo, B., Kpera, G.N., Pomalegni, S.C.B. (2007):Inventory of simple and mixed feedstuffs used for feeding the bred grass cutter in south and the centre of Benin. Bul. Rec. Agr. Benin, 57 : 1-7.

38. Toléba, S.S., Youssao, A.K.I.,Dahouda, M.,Missainhoun, U.M.A.,Mensah, G.A.(2009):Identification and nutritious values of feedstuffs used on grass-cutter(Thryonomys swinderianus) breeding in Cotonou and PortoNovo in Benin. Bul. Rec. Agr. Bénin, 64 :1-10.

39. Traoré, B.(2010): Analyse de quelques activités enzymatiques digestives et influence d'aliments complets granulés sur des performances zootechniques de l'aulacode (Thryonomys swinderianus) d'élevage, Thèse de doctorat, Université Abobo-Adjamè, Côte d'Ivoire. 251 p.

40. Traoré, B., Fantodji, A., Allou V.K.(2008):Digestibility in vivo to the grasscutter(Thryonomys swinderianus).Arch. ZooteC. 57(218) : 229-234.

41. Traoré, B., Fantodji, A., Mensah, G.A. (2009):Influence of diets physical presentation on the growth and carcass yield of Thryonomys swinderianusin three physiological stages. Bul. Rec. Agr. Bénin, 65: 1-31.

42. Uwalaka, R.E., and Ahaotu, E.O.(2013): Performance of Growing grasscutters fed on different fibre sources. Inter. J. Vet. Sci., 2(3): 85-87.

43. Van Soest, P.J., Robertson J.B. and Lewis B.A. (1991): Methods for dietary fiber, neutral detergent fiber, and non-starch polysaccharides in relation to animal nutrition. J. of Dairy Sci, 74: 3583-3597.

44. Van Zyl, A., Meyer A.J. \&Merwe,V.M.(1999): The influence of fibre in the diet on growth rates and digestibility of nutrients in the greater cane rat (Thryonomis swinderianus). Comparative Biochemistry and Physiology, Part A: Molecular and Integrative Physiology., 123(2): 129-135. http://dx.doi.org/10.1016/S10956433 (99) 00034-3. 
45. WogarIkani, G.S.(2011): Performance of Growing Grasscutters (Thryonomys swinderianus) Fed Cassava-Based Diets with Gradel Protein Levels. World J. Agri. Sci, 7(5): 510-514.

46. Wogar G.S.I., Agwunobi, L.N.,\&Anieunam. A.S.(2007): Effect of replacing cassava meal with dried milled elephant grass (Pennisetumpurpureum) on the performance of growing grasscutters (Thryonomys swinderianus). In: Proceeding of 32nd Annual Conference of Nigerian Society of Animal Production (pp. 365368). UNICAL, Calabar,

47. Wogar, G.S.I.(2012): Performance of Growing Grasscutters on Different Fibre Sources. Pak. J. Nutr. 11(1): 5153.

48. Wogar, G.S.I.\&Ayuk A.A.(2012): By-Products as Protein Source for Lactating Grasscutters. J. Agri. Sci, 4(7); 2012. 148-153.

49. Wogar, G.S.I.(2015): Growth and Reproductive Performance of Grasscutter Does with Litter Varying Levels of Cassava-based Energy Diet. J. Agri. Ecol. Res. Int, 4(1): 36-42.

50. Wogar, G.S.I., Ufot, M.L., Henry, A.J., InyangI.E. \&Efe,E.E. (2013): Composition and Emulsifying Characteristics of Grasscutters Meat from Varying Dietary Levels. J. Agri. Sci, 5(1), 314-318.

51. Wogar, G.S.I. and Ayara,T.E.(2015): Performance of Growing Grasscutters fed a concentrate diet without supplementation. American Journal of Experimental Agriculture, 8(4): 253-260.

52. Yapi, Y.M. (2013) : Physiologie digestive de l'aulacode (Thryonomys swinderianus) en croissance et impact des teneurs en fibres et céréales de la ration sur la santé et les performances zootechniques. Thèse de Doctorat, Université de Toulouse, Toulouse (France), 227p. 